\title{
Ethylene glycol dry reforming for syngas generation on Ce-promoted $\mathrm{Co} / \mathrm{Al}_{2} \mathrm{O}_{3}$ catalysts
}

\author{
Lau N. Jun ${ }^{1}$ Mahadi B. Bahari ${ }^{1}$. Pham T. T. Phuong ${ }^{2} \cdot$ Nguyen Huu Huy Phuc $^{3}$. Chanatip Samart ${ }^{4}$. \\ Bawadi Abdullah ${ }^{5} \cdot$ H. D. Setiabudi ${ }^{1} \cdot$ Dai-Viet N. Vo ${ }^{1,6}$ (])
}

Received: 7 June 2018 / Accepted: 6 December 2018 / Published online: 11 December 2018

(c) The Author(s) 2018

\begin{abstract}
Ethylene glycol dry reforming (EGDR) was investigated for the first time on $10 \% \mathrm{Co} / \mathrm{Al}_{2} \mathrm{O}_{3}$ and $3 \% \mathrm{Ce}-10 \% \mathrm{Co} / \mathrm{Al}_{2} \mathrm{O}_{3}$ catalysts at stoichiometric feed composition under atmospheric pressure and $923-998 \mathrm{~K}$ for syngas production. Catalysts were characterized using BET, $\mathrm{H}_{2}$-TPR, XRD and Raman spectroscopy measurements. The addition of Ce promoter eased the reduction of $\mathrm{Co}_{3} \mathrm{O}_{4}$ with lower reduction temperature and enhanced metal dispersion. Ce promotion also improved EGDR performance by increasing reactant conversions, syngas yields and reducing undesirable methane formation. The conversion of ethylene glycol and $\mathrm{H}_{2}$ yield reached up to $71.7 \%$ and $69.3 \%$, respectively.
\end{abstract}

Keywords Ethylene glycol $\cdot$ Dry reforming $\cdot$ Co-based catalysts $\cdot$ Syngas $\cdot$ Ce promoter $\cdot$ Hydrogen

\section{Introduction}

The extensive use of fossil fuels for transportation and industrial production has led to severe environmental pollution related to $\mathrm{CO}_{2}$ greenhouse gas emissions [1]. At the same time, global oil reserves are depleting rapidly and hence,

Dai-Viet N. Vo

vietvo@ump.edu.my

1 Faculty of Chemical and Natural Resources Engineering, Universiti Malaysia Pahang, Lebuhraya Tun Razak, Gambang, 26300 Pahang, Malaysia

2 Institute of Chemical Technology, Vietnam Academy of Science and Technology, 1 Mac Dinh Chi Str., Dist. 1, Ho Chi Minh, Viet Nam

3 Department of Electrical and Electronic Information Engineering, Toyohashi University of Technology, 1-1 Hibarigaoka, Tempaku, Toyohashi, Aichi 441-8580, Japan

4 Department of Chemistry, Faculty of Science and Technology, Thammasat University, Klongluang, Pathumtani 12120, Thailand

5 Biomass Processing Laboratory, Centre for Biofuel and Biochemical Research, Chemical Engineering Department, Universiti Teknologi Petronas, Bandar Seri Iskandar, 32610 Perak, Malaysia

6 Centre of Excellence for Advanced Research in Fluid Flow, Universiti Malaysia Pahang, Gambang, 26300 Kuantan, Pahang, Malaysia there is a dire need to find new alternative and sustainable energy sources. Considerable attention has been dedicated to search for renewable energies to partially replace petroleumbased resources. The use of bio-renewable organic sources including biomass-derived oxygenated compounds as feedstocks in catalytic reforming processes to yield syngas for synthetic fuel production has emerged as a promising solution $[2,3]$. Syngas is a mixture of $\mathrm{H}_{2}$ and $\mathrm{CO}$ which acts as building block for Fischer-Tropsch synthesis (FTS) to produce long-chain hydrocarbons followed by refinery to generate synthetic fuels and valuable petrochemicals [4,5].

Amongst the oxygenated compounds, ethylene glycol (EG) emerges as an alluring feedstock for syngas generation because it is the simplest polyol, major bio-oil constituent and can be derived from cellulose and sugar [6-8]. At present, there are two existing EG reforming techniques for syngas generation, namely, aqueous phase reforming and steam reforming. The aqueous phase reforming is normally conducted at moderate temperature and high pressure (explicitly, $T=498-723 \mathrm{~K}$ and $P=2.9-25 \mathrm{MPa}$ ) [9], whereas steam reforming of EG is conventionally operated at atmospheric pressure. However, these current reforming techniques consume significant quantity of water and release excessive amounts of undesirable $\mathrm{CO}_{2}$ to environment (cf. Eq. 1):

$\mathrm{C}_{2} \mathrm{H}_{6} \mathrm{O}_{2}+2 \mathrm{H}_{2} \mathrm{O} \rightarrow 5 \mathrm{H}_{2}+2 \mathrm{CO}_{2}$ 
In this regard, ethylene glycol dry reforming, EGDR [see Eq. (2)] appears as an attractive and green reforming process, since it consumes $\mathrm{CO}_{2}$ greenhouse gas and biomass-derived EG to generate syngas with a low $\mathrm{H}_{2} /$ $\mathrm{CO}$ ratio suitable for FTS $[4,5]$. Although aqueous phase reforming and steam reforming processes of ethylene glycol were substantially inspected on diverse catalysts for syngas production, EGDR process has not been investigated before in literature. Thus, it is crucial to explore this novel technique to produce ecofriendly and desirable syngas from low-valued and unwanted reactants:

$\mathrm{C}_{2} \mathrm{H}_{6} \mathrm{O}_{2}+\mathrm{CO}_{2} \rightarrow 3 \mathrm{CO}+2 \mathrm{H}_{2}+\mathrm{H}_{2} \mathrm{O}$

Cobalt-based catalysts have been widely implemented as catalyst for various reforming techniques (such as ethanol steam reforming [10], ethanol dry reforming [11], methane dry reforming $[12,13]$ and EG steam reforming $[14,15])$ and exhibited outstanding performance. However, carbon deposition on catalyst surface is the common setback observed for cobalt catalyst [16]. Ceria promoter was recently reported to impede carbonaceous formation in reforming processes, since its high reducibility, oxygen mobility and oxygen storage capacity arising from $\mathrm{Ce}^{4+} \leftrightarrow \mathrm{Ce}^{3+}$ redox cycle could gasify carbon deposits from catalyst surface $[11,17,18]$. Therefore, the goal of this work is to examine the feasibility of EGDR on Ce-promoted $\mathrm{Co} / \mathrm{Al}_{2} \mathrm{O}_{3}$ catalysts at different reaction temperatures.

\section{Experimental}

\section{Catalyst synthesis}

$10 \% \mathrm{Co} / \mathrm{Al}_{2} \mathrm{O}_{3}$ catalyst was prepared using an incipient wetness impregnation (IWI) approach. The pretreatment of $\gamma-\mathrm{Al}_{2} \mathrm{O}_{3}$ support (Sasol, Puralox SCCa-150/200) was done by calcination in flowing air at $1023 \mathrm{~K}$ for $5 \mathrm{~h}$ to avoid structural alteration during catalytic tests. Then, the calcined $\gamma-\mathrm{Al}_{2} \mathrm{O}_{3}$ support was blended with an accurately balanced amount of $\mathrm{Co}\left(\mathrm{NO}_{3}\right)_{2} \cdot 6 \mathrm{H}_{2} \mathrm{O}$ (Sigma-Aldrich) aqueous solution in a BÜCHI Rotavapor R-200 rotary evaporator for $2 \mathrm{~h}$. The soaked solid was dried overnight at $333 \mathrm{~K}$ in an oven and calcined in air for $5 \mathrm{~h}$ at $1023 \mathrm{~K}$ (ramping rate $5 \mathrm{~K} \mathrm{~min}^{-1}$ ). The sequential IWI method was implemented for preparing $3 \% \mathrm{Ce}-10 \% \mathrm{Co} / \mathrm{Al}_{2} \mathrm{O}_{3}$. In particular, $10 \% \mathrm{Co} / \mathrm{Al}_{2} \mathrm{O}_{3}$ was further impregnated with $\mathrm{Ce}\left(\mathrm{NO}_{3}\right)_{3} \cdot 6 \mathrm{H}_{2} \mathrm{O}$ (Merck Millipore) as promoter precursor using the aforesaid IWI conditions. Both catalysts were crushed in mortar using pestle followed by sieving to desired particle size $(125-160 \mu \mathrm{m})$.

\section{Catalyst characterization}

Brunauer-Emmett-Teller (BET) surface area, total pore volume and pore diameter were determined in a Micromeritics TriStar II 3020 V1.04 instrument at $77 \mathrm{~K}$. All samples were outgassed at $573 \mathrm{~K}$ for $1 \mathrm{~h}$ in $\mathrm{N}_{2}$ flow prior to measurements to eliminate traced moisture and foreign adsorbed molecules. $\mathrm{H}_{2}$ temperature-programmed reduction $\left(\mathrm{H}_{2}\right.$-TPR) was achieved from a Micromeritics AutoChem II-2920 chemisorption system. Catalyst (roughly $0.1 \mathrm{~g}$ ) placed in a U-tube (quartz) by quartz wool was pretreated at $373 \mathrm{~K}$ for $30 \mathrm{~min}$ in $\mathrm{He}$ gas $\left(50 \mathrm{ml} \mathrm{min}{ }^{-1}\right)$ before being reduced in $10 \% \mathrm{H}_{2} / \mathrm{Ar}\left(50 \mathrm{ml} \mathrm{min}^{-1}\right)$ from 373 to $1173 \mathrm{~K}$ with a linear heating rate $\left(10 \mathrm{~K} \mathrm{~min}^{-1}\right)$. Specimen was retained at final temperature for $30 \mathrm{~min}$ and then quenched to ambient temperature.

The crystal structure of fresh calcined, reduced and spent catalysts was examined in a Rigaku Miniflex II X-ray powder diffraction (XRD) system employing $\mathrm{Cu}$ as the radiation source. This unit was operated at $30 \mathrm{~kW}$ and $15 \mathrm{~mA}$ with wavelength, $\lambda$ of $1.5418 \AA$; whereas diffraction patterns were verified from $2 \theta=3^{\circ}$ to $80^{\circ}$ with small scan speed and step size of $1 \mathrm{~min}^{-1}$ and $0.02^{\circ}$ in that order to yield a high resolution. The JASCO NRS-3100 system was employed for Raman analyses of spent catalysts. A 532-nm green laser with laser power less than $5 \mathrm{~mW}$ was used during Raman measurements.

Temperature-programmed oxidation (TPO) was performed on TGA Q500 thermogravimetric unit (TA Instruments) for the precise quantification of deposited carbon on used catalysts. After being treated with flowing $\mathrm{N}_{2}$ gas $\left(100 \mathrm{ml} \mathrm{min}{ }^{-1}\right)$ for $0.5 \mathrm{~h}$ at $373 \mathrm{~K}$ to remove moisture, $20 \% \mathrm{O}_{2} / \mathrm{N}_{2}$ oxidizing mixture was purged through spent catalysts with temperature increment from 373 to $1023 \mathrm{~K}$ $\left(10 \mathrm{~K} \mathrm{~min}^{-1}\right)$ for the successful oxidation of carbonaceous species. Afterward, the final temperature was kept constant for $30 \mathrm{~min}$ in the same gaseous mixture.

\section{Ethylene glycol dry reforming experiments}

EGDR tests were done at atmospheric pressure, stoichiometric feed ratio $\left(\mathrm{Co}_{3} \mathrm{O}_{4}+\mathrm{H}_{2} \rightarrow 3 \mathrm{CoO}+\mathrm{H}_{2} \mathrm{O}\right)$ and 923-998 K in a standard stainless-steel fixed-bed continuous flow reactor for $8 \mathrm{~h}$ with total flow rate of $70 \mathrm{ml} \mathrm{min}$. Quartz wool was used to hold around $0.1 \mathrm{~g}$ of catalyst in the middle of the reactor. Catalyst was activated in $50 \%$ $\mathrm{H}_{2} / \mathrm{N}_{2}\left(60 \mathrm{ml} \mathrm{min}{ }^{-1}\right)$ at $1023 \mathrm{~K}$ for $2 \mathrm{~h}$ and then purged in $\mathrm{N}_{2}$ flow for 30 min prior to reaction. After being pumped by a precise KellyMed KL-602 syringe pump through a pre-heater, vaporised EG was fed to the top of reactor where it was mixed with $\mathrm{CO}_{2}$ reactant and $\mathrm{N}_{2}$ diluent 
(regulated by Alicat mass flow controllers). Gas hourly space velocity was kept at $42 \mathrm{lg}_{\text {cat }}^{-1} \mathrm{~h}^{-1}$ during each run. The composition of gaseous outlet from reactor was determined in Agilent 6890 Series GC system using TCD detector. $\mathrm{N}_{2}$ internal standard was continuously measured with time on stream to assure the high accuracy of GC analysis and experimental works. The error of nitrogen balance was less than $3.76 \%$ for all runs, whilst the relative error among repeated experiments at similar conditions was smaller than $6.32 \%$.

EGDR reaction metrics including reactant conversion $\left(X_{i}\right.$; $i$ : $\mathrm{C}_{2} \mathrm{H}_{6} \mathrm{O}_{2}$ or $\mathrm{CO}_{2}$ ) and gaseous product yield, $Y$ are given in Eqs. (3)-(6). The conversion of EG into gaseous products was estimated based on atomic $\mathrm{H}$ balance as shown in Eq. (3); whereas $F^{\text {in }}$ and $F^{\text {out }}$ refer to inlet and outlet molar flow rates of the corresponding components:

$$
\begin{aligned}
& X_{\mathrm{C}_{2} \mathrm{H}_{6} \mathrm{O}_{2}}(\%)=\frac{2 F_{\mathrm{H}_{2}}^{\text {out }}+4 F_{\mathrm{CH}_{4}}^{\text {out }}}{6 F_{\mathrm{C}_{2} \mathrm{H}_{6} \mathrm{O}_{2}}^{\text {in }}} \times 100 \% \\
& X_{\mathrm{CO}_{2}}(\%)=\frac{F_{\mathrm{CO}_{2}}^{\text {in }}-F_{\mathrm{CO}_{2}}^{\text {out }}}{F_{\mathrm{CO}_{2}}^{\text {in }}} \times 100 \% \\
& Y_{\mathrm{H}_{2}}(\%)=\frac{2 F_{\mathrm{H}_{2}}^{\text {out }}}{6 F_{\mathrm{C}_{2} \mathrm{H}_{6} \mathrm{O}_{2}}^{\text {on }}} \times 100 \% \\
& Y_{j}(\%)=\frac{F_{j}^{\text {out }}}{2 F_{\mathrm{C}_{2} \mathrm{H}_{6} \mathrm{O}_{2}}^{\text {in }}+F_{\mathrm{CO}_{2}}^{\text {in }}} \times 100 \% ; j: \mathrm{CH}_{4} \text { or } \mathrm{CO}
\end{aligned}
$$

\section{Results and discussion}

\section{Textural properties of catalysts}

The physical features of fresh $10 \% \mathrm{Co} / \mathrm{Al}_{2} \mathrm{O}_{3}$ and $3 \%$ $\mathrm{Ce}-10 \% \mathrm{Co} / \mathrm{Al}_{2} \mathrm{O}_{3}$ are summarized in Table 1 . A minor drop in BET surface area with $\mathrm{Ce}$ addition from 142.9 to $134.7 \mathrm{~m}^{2} \mathrm{~g}^{-1}$ (about $5.7 \%$ ) was observed; whereas the total pore volume of both catalysts seemed to be equivalent. These results could be indicative of uniform dispersion of Ce promoter on catalyst surface.

\section{$\mathrm{H}_{2}$ temperature-programmed reduction}

Figure 1 shows the reduction behavior of both catalysts during $\mathrm{H}_{2}$-TPR. Three deconvoluted $\mathrm{H}_{2}$ consumption peaks are observed and labeled as P1, P2 and P3. The $\mathrm{H}_{2}$-reduction of $\mathrm{Co}_{3} \mathrm{O}_{4}$ phase was broadly regarded as a two-step procedure in which $\mathrm{Co}_{3} \mathrm{O}_{4}$ was firstly reduced to $\mathrm{CoO}$ phase [cf. Eq. (7)] followed by reduction to metallic $\mathrm{Co}^{0}$ [cf. Eq. (8)] $[11,20]$. As a result, low-temperature peaks $\mathrm{P} 1$ and $\mathrm{P} 2$ ranging from 650 to $900 \mathrm{~K}$ were ascribed to the reduction of $\mathrm{Co}_{3} \mathrm{O}_{4}$ to $\mathrm{CoO}$ and $\mathrm{CoO}$ to $\mathrm{Co}^{0}$, respectively.

$$
\begin{aligned}
& \mathrm{Co}_{3} \mathrm{O}_{4}+\mathrm{H}_{2} \rightarrow 3 \mathrm{CoO}+\mathrm{H}_{2} \mathrm{O} \\
& \mathrm{CoO}+\mathrm{H}_{2} \rightarrow \mathrm{Co}+\mathrm{H}_{2} \mathrm{O}
\end{aligned}
$$

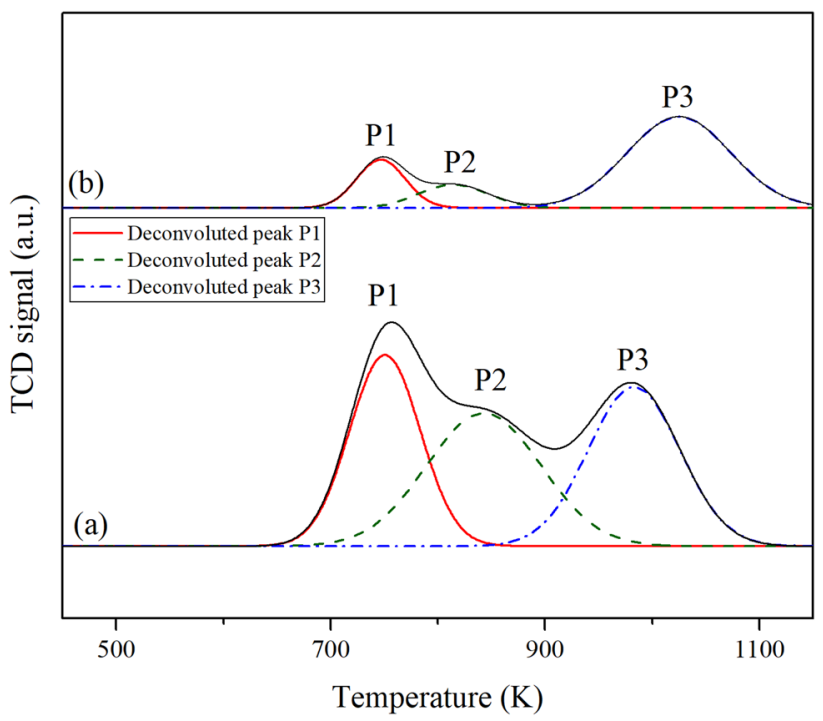

Fig. $1 \mathrm{H}_{2}$-TPR profiles of a $10 \% \mathrm{Co} / \mathrm{Al}_{2} \mathrm{O}_{3}$ and b $3 \% \mathrm{Ce}-10 \% \mathrm{Co} /$ $\mathrm{Al}_{2} \mathrm{O}_{3}$
Table 1 Textural attributes of $10 \% \mathrm{Co} / \mathrm{Al}_{2} \mathrm{O}_{3}$ and $3 \% \mathrm{Ce}-10 \%$ $\mathrm{Co} / \mathrm{Al}_{2} \mathrm{O}_{3}$

\begin{tabular}{llllc}
\hline Sample & $\begin{array}{l}\text { BET surface area } \\
\left(\mathrm{m}^{2} \mathrm{~g}^{-1}\right)\end{array}$ & $\begin{array}{l}\text { Total pore volume } \\
\left(\mathrm{cm}^{3} \mathrm{~g}^{-1}\right)^{\mathrm{a}}\end{array}$ & $\begin{array}{l}\text { Average pore } \\
\text { diameter }(\mathrm{nm})^{\mathrm{b}}\end{array}$ & $\begin{array}{l}\mathrm{Co}_{3} \mathrm{O}_{4} \text { aver- } \\
\text { age crystallite } \\
\text { size }(\mathrm{nm})^{\mathrm{c}}\end{array}$ \\
\hline $10 \% \mathrm{Co} / \mathrm{Al}_{2} \mathrm{O}_{3}$ & 142.9 & 0.39 & 8.0 & 21.4 \\
$3 \% \mathrm{Ce}-10 \% \mathrm{Co} / \mathrm{Al}_{2} \mathrm{O}_{3}$ & 134.7 & 0.37 & 8.4 & 9.2 \\
\hline
\end{tabular}

Total pore volume was obtained at $p / p^{0}=0.99$

${ }^{\mathrm{b}}$ Barrett-Joyner-Halenda (BJH) desorption method was used for achieving average pore diameter ${ }^{c}$ Average $\mathrm{Co}_{3} \mathrm{O}_{4}$ crystallite size was estimated by Scherrer equation [19] for the most intense $\mathrm{Co}_{3} \mathrm{O}_{4}$ peak at $2 \theta=31.2^{\circ}$ 
Remarkably, as seen in Fig. 1, both peaks P1 and P2 of $\mathrm{Ce}$-doped catalyst shifted towards lower temperature region in comparison with $10 \% \mathrm{Co} / \mathrm{Al}_{2} \mathrm{O}_{3}$. The addition of $\mathrm{CeO}_{2}$ promoter facilitated $\mathrm{Co}_{3} \mathrm{O}_{4}$ reduction plausibly because of extra electron density on $\mathrm{Co}_{3} \mathrm{O}_{4}$ donated by $\mathrm{CeO}_{2}$, thereby relieving reduction procedure [11]. The formation of the third peak, P3 at temperature above $900 \mathrm{~K}$ for both samples corresponds to the reduction of spinel $\mathrm{CoAl}_{2} \mathrm{O}_{4}$ [see Eq. (9)], normally formed due to diffusion of Co ions into the vacancies in lattice sites of $\mathrm{Al}_{2} \mathrm{O}_{3}$ during calcination at high temperature [21]. Since the trivalent $\mathrm{Co}^{3+}$ and $\mathrm{Al}^{3+}$ ions have similar ionic radii of 0.063 and $0.054 \mathrm{~nm}$, respectively, $\mathrm{Co}^{3+}$ ions in $\mathrm{Co}_{3} \mathrm{O}_{4}$ could be substituted by $\mathrm{Al}^{3+}$ ions to yield $\mathrm{CoAl}_{2} \mathrm{O}_{4}$ phase having strong metal-support interaction, thereby inducing high reduction temperature [22]. Notably, the reduction temperature for peak P3 of 3\% $\mathrm{Ce}-10 \% \mathrm{Co} / \mathrm{Al}_{2} \mathrm{O}_{3}$ was superior to that of $10 \% \mathrm{Co} / \mathrm{Al}_{2} \mathrm{O}_{3}$ as seen in Fig. 1. It could be caused by double calcination during sequential IWI and hence a greater amount of $\mathrm{CoAl}_{2} \mathrm{O}_{4}$ could be yielded with a stronger degree of metal-support interaction:

$$
\mathrm{CoAl}_{2} \mathrm{O}_{4}+\mathrm{H}_{2} \rightarrow \mathrm{Co}+\mathrm{Al}_{2} \mathrm{O}_{3}+\mathrm{H}_{2} \mathrm{O}
$$

\section{$\mathrm{X}$-ray diffraction measurements}

Figure 2 presents the XRD patterns of fresh calcined and reduced catalysts. The $\mathrm{X}$-ray diffractograms of calcined $\gamma-\mathrm{Al}_{2} \mathrm{O}_{3}$ support is provided to ease the peak assignments. All XRD patterns were examined with the employment of database library from Joint Committee on Powder Diffraction Standards (JCPDS) [23]. All catalysts show five characteristic peaks belonging to $\gamma$-alumina at $2 \theta=18.9^{\circ}$, $32.5^{\circ}, 37.0^{\circ}, 45.6^{\circ}$ and $67.1^{\circ}$ (JCPDS No. 04-0858) [11,

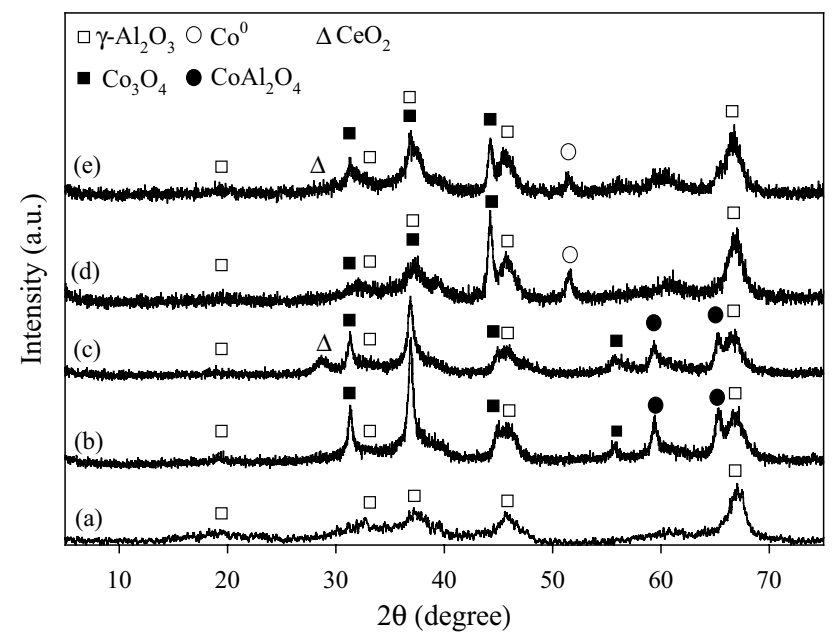

Fig. 2 XRD patterns of a calcined $\gamma-\mathrm{Al}_{2} \mathrm{O}_{3}$ support, b calcined $10 \%$ $\mathrm{Co} / \mathrm{Al}_{2} \mathrm{O}_{3}$, c calcined $3 \% \mathrm{Ce}-10 \% \mathrm{Co} / \mathrm{Al}_{2} \mathrm{O}_{3}$, d reduced $10 \% \mathrm{Co} /$ $\mathrm{Al}_{2} \mathrm{O}_{3}$ and e reduced $3 \% \mathrm{Ce}-10 \% \mathrm{Co} / \mathrm{Al}_{2} \mathrm{O}_{3}$
24]. Cubic spinel $\mathrm{Co}_{3} \mathrm{O}_{4}$ phase ( $2 \theta$ located at $31.2^{\circ}, 37.0^{\circ}$, $45.0^{\circ}$ and $\left.55.7^{\circ}\right)$ and $\mathrm{CoAl}_{2} \mathrm{O}_{4}$ form $\left(2 \theta=59.4^{\circ}\right.$ and $\left.65.3^{\circ}\right)$ were found on both calcined promoted and unpromoted samples (Fig. 2b, c) based on JCPDS No. 74-2120 and JCPDS No. 82-2246, respectively [23]. The presence of $\mathrm{Co}_{3} \mathrm{O}_{4}$ and $\mathrm{CoAl}_{2} \mathrm{O}_{4}$ phases is consistent with peak assignment in $\mathrm{H}_{2}$-TPR measurement (see Fig. 1). For the calcined promoted catalyst, $\mathrm{CeO}_{2}$ phase was detected at $2 \theta=28.8^{\circ}$ (see Fig. 2c) according to JCPDS No. 34-0394 [18]. The $\mathrm{CeO}_{2}$ form was most likely produced from the oxidation of $\mathrm{Ce}_{2} \mathrm{O}_{3}$ previously yielded by $\mathrm{Ce}\left(\mathrm{NO}_{3}\right)_{3}$ thermal decomposition. For the reduced catalysts (Fig. $2 \mathrm{~d}$, e), the absence of $\mathrm{CoAl}_{2} \mathrm{O}_{4}$ phase further reinforces the complete $\mathrm{H}_{2}$ reduction of $\mathrm{CoAl}_{2} \mathrm{O}_{4}$ form [see Eq. (9)] in agreement with $\mathrm{H}_{2}$-TPR (cf. Fig. 1). The $\mathrm{Co}^{0}$ metallic phase appearing in the XRD patterns of both reduced catalysts at $2 \theta$ diffractive peak about $51.5^{\circ}$ (JCPDS No. 15-0806) was assigned to $\mathrm{Co}_{3} \mathrm{O}_{4} \rightarrow \mathrm{Co}$ reduction in $\mathrm{H}_{2}$ activation [23]. Based on $\mathrm{H}_{2}$-TPR results (Fig. 1), $\mathrm{Co}_{3} \mathrm{O}_{4}$ was reduced thoroughly to final $\mathrm{Co}^{0}$ form at below $1000 \mathrm{~K}$. Thus, the co-presence of $\mathrm{Co}_{3} \mathrm{O}_{4}$ phase on reduced catalysts was because of inevitable Co re-oxidation in air during ex situ XRD measurements.

The average crystallite size of $\mathrm{Co}_{3} \mathrm{O}_{4}$ phase for both catalysts was estimated using the Scherrer equation for the highest peak $\left(2 \theta=31.2^{\circ}\right)$ [19]. As listed in Table 1 , Ce promotion reduced substantially $\mathrm{Co}_{3} \mathrm{O}_{4}$ crystallite size from 21.4 to $9.2 \mathrm{~nm}$. The tiny crystallite size of Ce-promoted catalyst less than $10 \mathrm{~nm}$ could indicate the fine distribution of $\mathrm{Co}_{3} \mathrm{O}_{4}$ on support surface. The enhancing metal dispersion for promoted catalyst was possibly attributed to the dilution effect in which $\mathrm{CeO}_{2}$ promoter could dilute $\mathrm{Co}_{3} \mathrm{O}_{4}$ particles, thereby preventing them from agglomeration.

\section{Ethylene glycol dry reforming evaluation}

Figure 3 shows the influence of temperature varied from 923 to $998 \mathrm{~K}_{\text {on }} \mathrm{C}_{2} \mathrm{H}_{6} \mathrm{O}_{2}$ and $\mathrm{CO}_{2}$ conversions at stoichiometric feedstock. Regardless of specimens, reactant conversions substantially increased with rising reaction temperature. This could be attributed to the endothermic nature of EGDR reaction. In particular, EG conversion grew from 59.0 to $71.7 \%$ with rising temperature from 923 to $998 \mathrm{~K}$ on $3 \%$ $\mathrm{Ce}-10 \% \mathrm{Co} / \mathrm{Al}_{2} \mathrm{O}_{3}$; whereas $\mathrm{CO}_{2}$ conversion enhanced from 38.3 to $48.7 \%$. As seen in Fig. 3, irrespective of catalysts, $\mathrm{EG}$ conversion was greater than $\mathrm{CO}_{2}$ conversion for all temperatures. This observation could indicate the presence of concomitant EG steam reforming side reaction [cf. Eq. (1)] during EGDR. This side reaction consumes EG but yields undesirable $\mathrm{CO}_{2}$ by-product and, hence, lessening $\mathrm{CO}_{2}$ conversion.

Notably, the overall catalytic activity was improved with Ce modification for all temperatures in terms of $\mathrm{CO}_{2}$ and $\mathrm{EG}$ conversions as shown in Fig. 3. The enhancement of reactant 


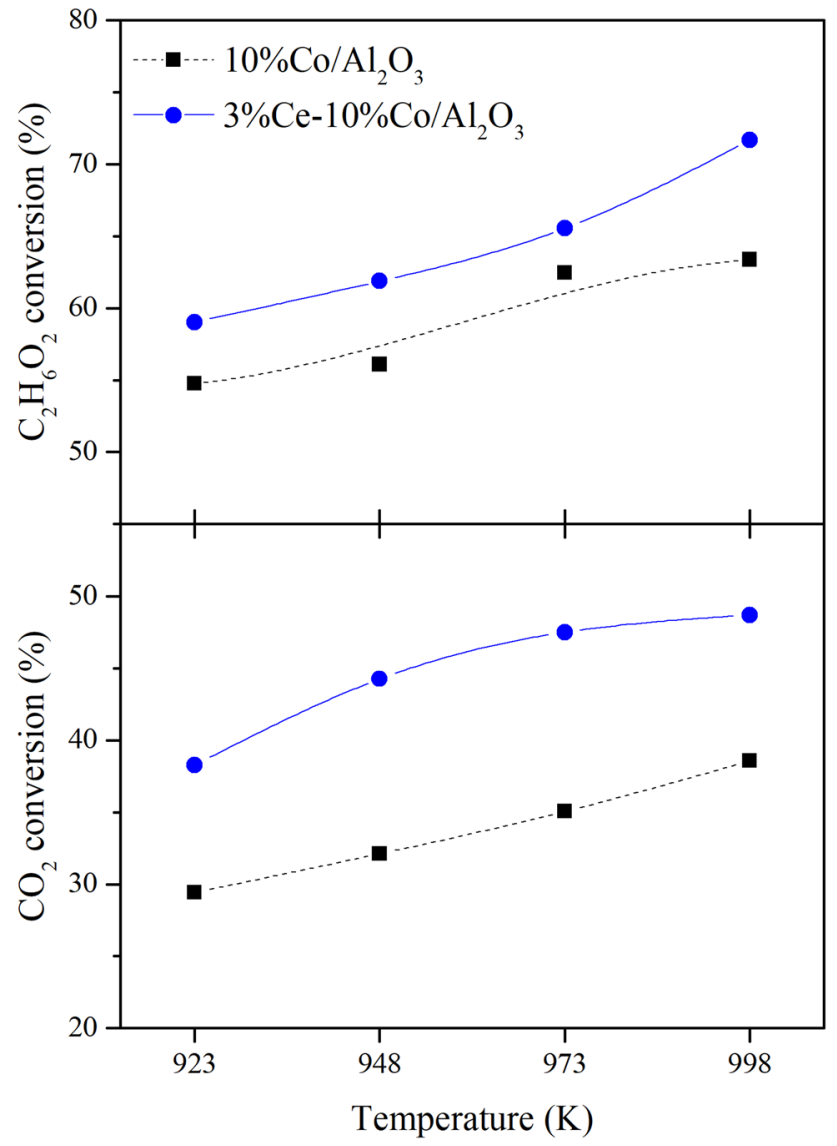

Fig. 3 Effect of temperature on $\mathrm{EG}$ and $\mathrm{CO}_{2}$ conversions at stoichiometric feed ratio $\left(F_{\mathrm{CO}_{2}}=F_{\mathrm{C}_{2} \mathrm{H}_{6} \mathrm{O}_{2}}\right)$

conversions could be assigned to the basic property of $\mathrm{CeO}_{2}$ promoter which could increase $\mathrm{CO}_{2}$ adsorption on catalyst surface. The high oxygen storage and release capacity of $\mathrm{CeO}_{2}$ also improve catalytic activity, since it could induce carbonaceous species gasification during EGDR, thereby maintaining the virgin catalyst surface $[11,25]$. In addition, the smaller $\mathrm{Co}_{3} \mathrm{O}_{4}$ crystallite size of $3 \% \mathrm{Ce}-10 \% \mathrm{Co} / \mathrm{Al}_{2} \mathrm{O}_{3}$ (see Table 1) due to high active metal dispersion could greatly contribute to the increasing reactant conversions.

The impact of Ce-dopant and temperature towards $\mathrm{H}_{2}$ and $\mathrm{CO}$ yields of $10 \% \mathrm{Co} / \mathrm{Al}_{2} \mathrm{O}_{3}$ is displayed in Fig. 4. The relationship between temperature and yield of $\mathrm{H}_{2}$ and $\mathrm{CO}$ also follows the similar trend of temperature vs. reactant conversions (see Fig. 3). In general, $\mathrm{H}_{2}$ and $\mathrm{CO}$ yields increased with increasing temperature from 923 to $998 \mathrm{~K}$ and reached up to $69.3 \%$ and $70.8 \%$ in this order. The rising syngas yield further confirms the enhancement of EGDR reaction with temperature.

Interestingly, $\mathrm{CH}_{4}$ by-product was also observed during EGDR (see Fig. 5). It could be formed from incomplete EG decomposition as given in Eq. (10). However, the amount of $\mathrm{CH}_{4}$ yield seemed to be negligible $(<2.5 \%)$ for both

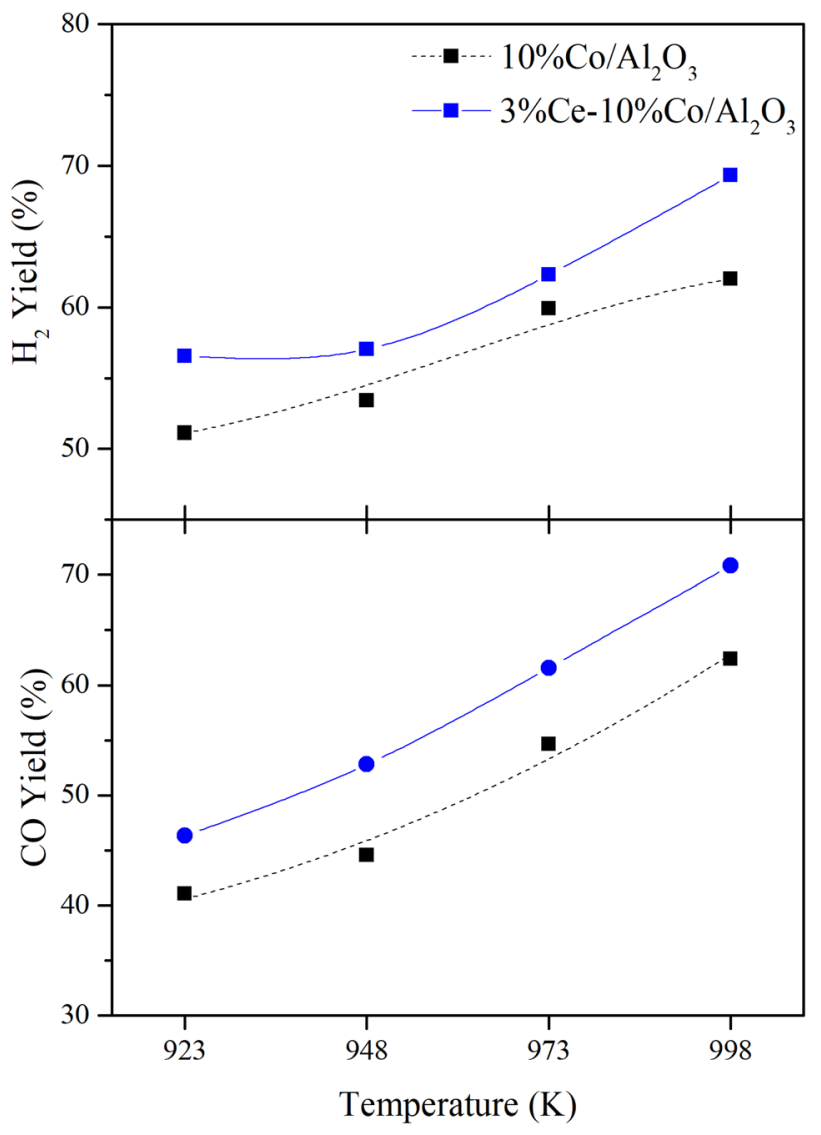

Fig. 4 Effect of temperature on $\mathrm{H}_{2}$ and $\mathrm{CO}$ yields at stoichiometric feed ratio $\left(F_{\mathrm{CO}_{2}}=F_{\mathrm{C}_{2} \mathrm{H}_{6} \mathrm{O}_{2}}\right)$

samples and lessened with rising temperature from 923 to $998 \mathrm{~K}$. The decreasing trend in the yield of $\mathrm{CH}_{4}$ intermediate product with temperature could be due to the occurrence of

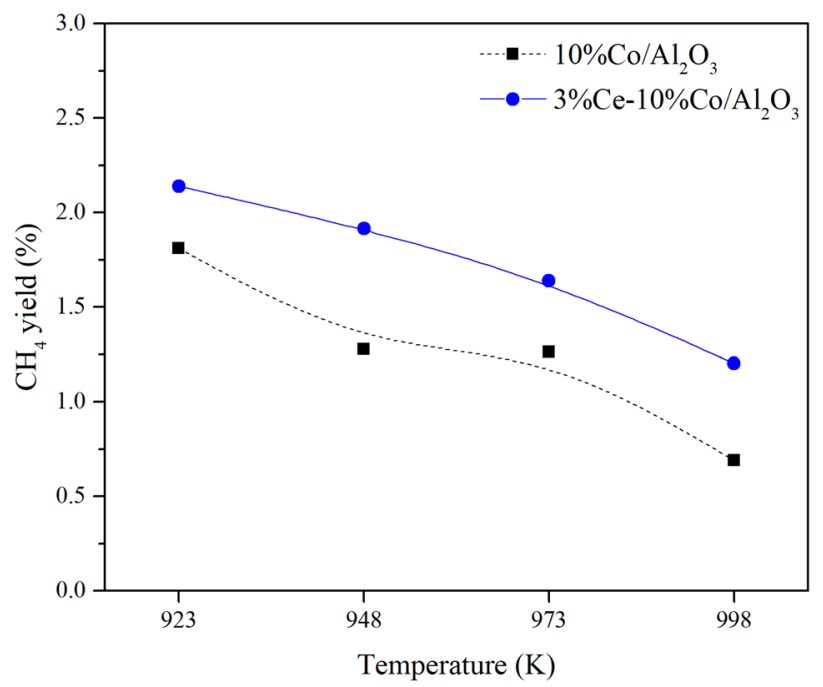

Fig. 5 Effect of temperature on $\mathrm{CH}_{4}$ yield at stoichiometric feed ratio $\left(F_{\mathrm{CO}_{2}}=F_{\mathrm{C}_{2} \mathrm{H}_{6} \mathrm{O}_{2}}\right)$ 
secondary reactions such as dry reforming of methane [cf. Eq. (11)] and steam reforming of methane [cf. Eq. (12)]. The significantly low $\mathrm{CH}_{4}$ yield is indicative of successful reforming of EG to final valuable syngas:

$$
\begin{aligned}
& \mathrm{C}_{2} \mathrm{H}_{6} \mathrm{O}_{2} \rightarrow \mathrm{CH}_{4}+\mathrm{CO}+\mathrm{H}_{2} \mathrm{O} \\
& \mathrm{CH}_{4}+\mathrm{CO}_{2} \rightarrow 2 \mathrm{H}_{2}+2 \mathrm{CO} \\
& \mathrm{CH}_{4}+\mathrm{H}_{2} \mathrm{O} \rightarrow 3 \mathrm{H}_{2}+\mathrm{CO}
\end{aligned}
$$

Figure 6 illustrates the influence of temperature on $\mathrm{H}_{2} / \mathrm{CO}$ ratio for both catalysts. Generally, regardless of catalysts, $\mathrm{H}_{2} /$ $\mathrm{CO}$ ratio decreases with increasing temperature as a result of thermodynamically preferred reverse water-gas shift (RWGS) and reverse Boudouard reactions [see Eqs. (13) and (14), respectively] concomitantly occurring during EGDR. However, the $\mathrm{H}_{2} / \mathrm{CO}$ ratios are still higher compared to the stoichiometric $\mathrm{H}_{2} / \mathrm{CO}$ value of 0.67 for EGDR [cf. Eq. (2)]. This phenomenon could be a result of EG steam reforming reaction [see Eq. (1)] between $\mathrm{H}_{2} \mathrm{O}$ (formed from EGDR) and $\mathrm{EG}$ to yield extra $\mathrm{H}_{2}$ product:

$$
\begin{aligned}
& \mathrm{H}_{2}+\mathrm{CO}_{2} \rightarrow \mathrm{CO}+\mathrm{H}_{2} \mathrm{O} \\
& \mathrm{C}+\mathrm{CO}_{2} \rightarrow 2 \mathrm{CO}
\end{aligned}
$$

Figure 7 displays the conversion envelopes of EG and $\mathrm{CO}_{2}$ reactants with time on stream. Irrespective of time on stream, $\mathrm{EG}$ and $\mathrm{CO}_{2}$ conversions on Ce-doped catalyst are greater than those of unpromoted counterpart. For unpromoted catalyst, EG and $\mathrm{CO}_{2}$ conversions declined substantially during $8 \mathrm{~h}$ with deactivation degree of $13.38 \%$ and $25.78 \%$, respectively (see Table 2); whereas, a slight

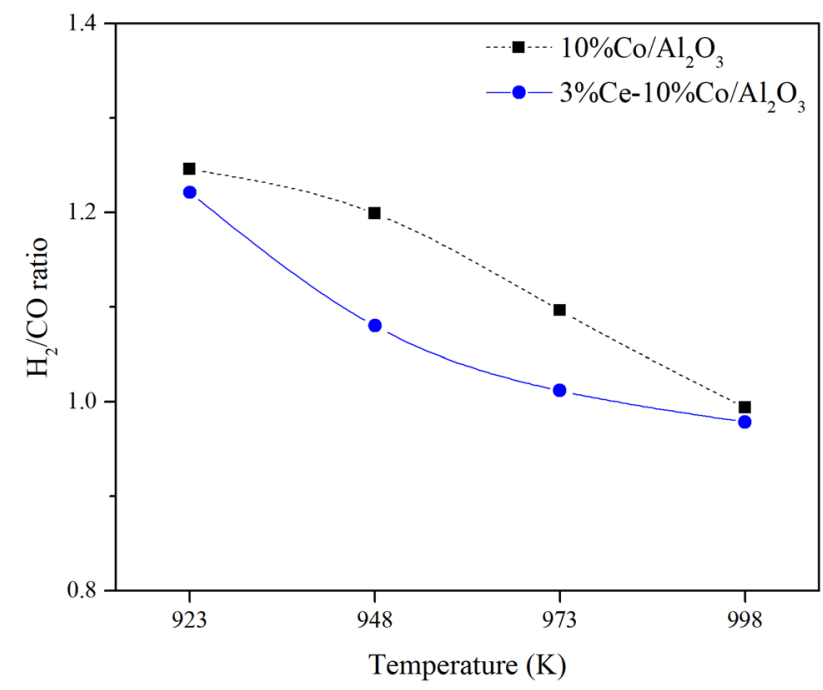

Fig. 6 Effect of temperature on $\mathrm{H}_{2} / \mathrm{CO}$ ratio at stoichiometric feed ratio $\left(F_{\mathrm{CO}_{2}}=F_{\mathrm{C}_{2} \mathrm{H}_{6} \mathrm{O}_{2}}\right)$

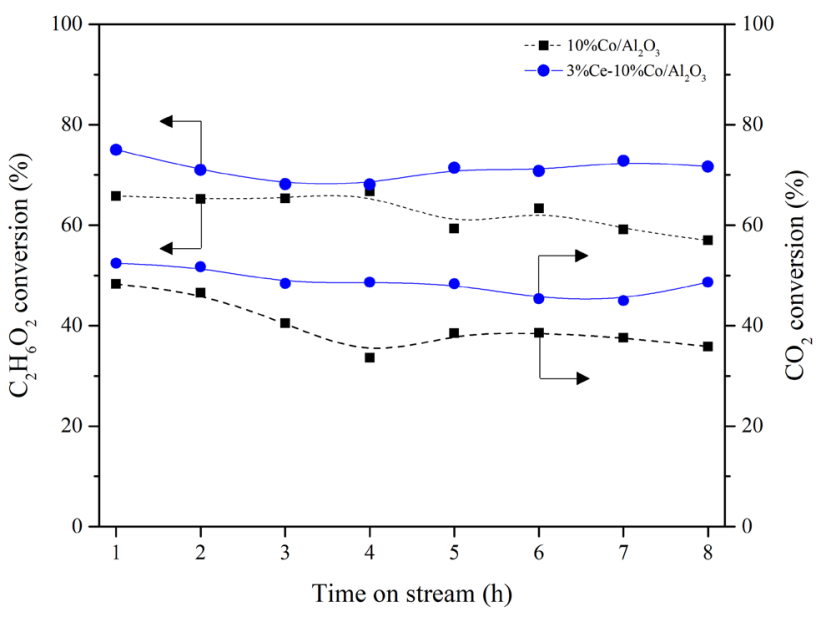

Fig. 7 Transient profiles of EG and $\mathrm{CO}_{2}$ conversions at stoichiometric feed $\left(F_{\mathrm{CO}_{2}}=F_{\mathrm{C}_{2} \mathrm{H}_{6} \mathrm{O}_{2}}\right)$ and $T=998 \mathrm{~K}$

decrease in catalytic activity was observed for $3 \% \mathrm{Ce}-10 \%$ $\mathrm{Co} / \mathrm{Al}_{2} \mathrm{O}_{3}$. In fact, the smaller degree of deactivation of $4.45 \%$ and $7.13 \%$ was evidenced for the corresponding EG and $\mathrm{CO}_{2}$ conversions on $3 \% \mathrm{Ce}-10 \% \mathrm{Co} / \mathrm{Al}_{2} \mathrm{O}_{3}$. The enhanced catalytic stability with $\mathrm{Ce}$ addition was owing to the high oxygen mobility and redox property of $\mathrm{CeO}_{2}$ promoter easing carbon removal during EGDR [11, 25].

\section{Characterization of spent catalysts}

The crystalline structure of spent catalysts after EGDR at stoichiometric feed composition and $T=998 \mathrm{~K}$ was examined by XRD measurements and shown in Fig. 8 . Both catalysts possessed broad peaks with high intensity at $2 \theta=26.4^{\circ}$ corresponding to graphitic carbon (JCPDS No. 75-0444) $[26,27]$. The presence of graphite on catalyst surface was inevitable, since EGDR was conducted at high reaction temperature $(\geq 923 \mathrm{~K})$ and deposited carbon was formed from EG decomposition. $\mathrm{Co}_{3} \mathrm{O}_{4}$ phase was also detected for both spent samples as a result of metallic $\mathrm{Co}^{0}$ oxidation when spent catalysts were exposed to air during catalyst discharge. However, the characteristic peak for $\mathrm{CeO}_{2}$ was not identified

Table 2 Degree of catalyst deactivation with time on stream on $10 \% \mathrm{Co} / \mathrm{Al}_{2} \mathrm{O}_{3}$ and $3 \% \mathrm{Ce}-10 \% \mathrm{Co} / \mathrm{Al}_{2} \mathrm{O}_{3}$ at stoichiometric feed $\left(F_{\mathrm{CO}_{2}}=F_{\mathrm{C}_{2} \mathrm{H}_{6} \mathrm{O}_{2}}\right)$ and $T=998 \mathrm{~K}$

\begin{tabular}{lll}
\hline Catalyst & \multicolumn{2}{l}{ Deactivation degree, $D(\%)^{\mathrm{a}}$} \\
\cline { 2 - 3 } & Ethylene glycol & Carbon dioxide \\
\hline $10 \% \mathrm{Co} / \mathrm{Al}_{2} \mathrm{O}_{3}$ & 13.38 & 25.78 \\
$3 \% \mathrm{Ce}-10 \% \mathrm{Co} / \mathrm{Al}_{2} \mathrm{O}_{3}$ & 4.45 & 7.13 \\
\hline
\end{tabular}

${ }^{\text {a }}$ Degree of catalyst deactivation $(\%)=(1-$ final reactant conversion/ initial reactant conversion) $\times 100 \%$ 


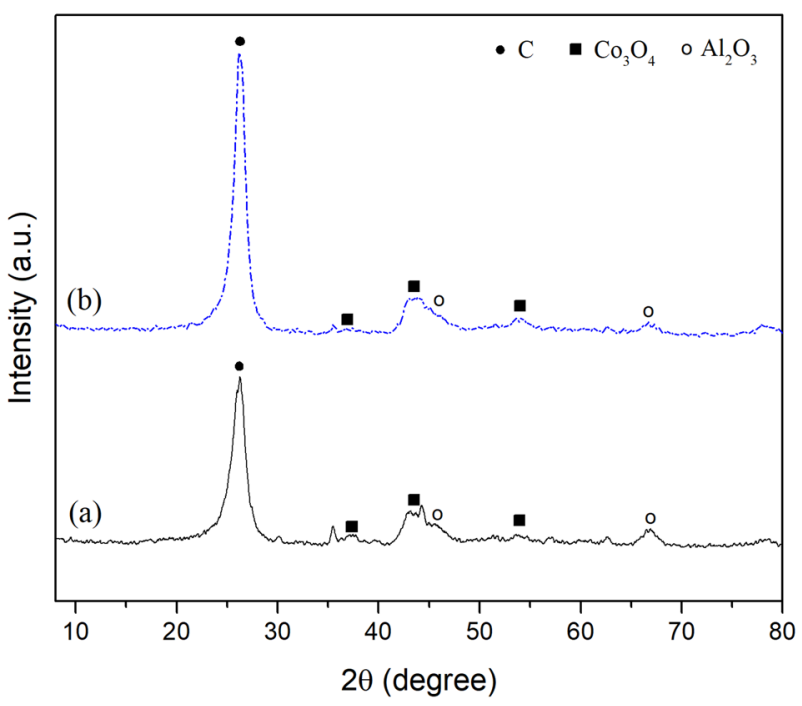

Fig. 8 XRD patterns of spent a $10 \% \mathrm{Co} / \mathrm{Al}_{2} \mathrm{O}_{3}$ and $\mathbf{b} 3 \% \mathrm{Ce}-10 \% \mathrm{Co} /$ $\mathrm{Al}_{2} \mathrm{O}_{3}$ after EGDR reaction at stoichiometric feed $\left(F_{\mathrm{CO}_{2}}=F_{\mathrm{C}_{2} \mathrm{H}_{6} \mathrm{O}_{2}}\right)$ and $T=998 \mathrm{~K}$

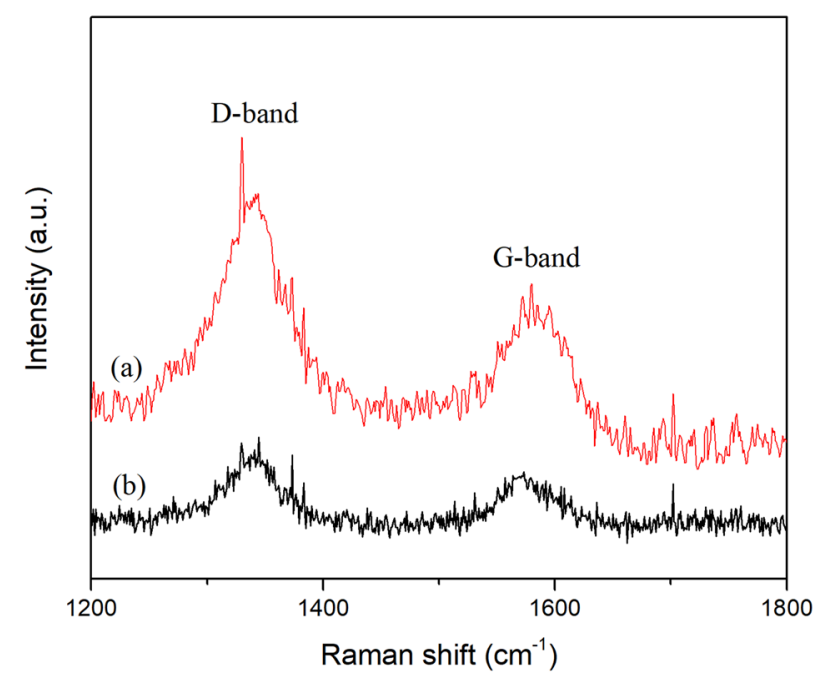

Fig. 9 Raman spectra of spent a $10 \% \mathrm{Co} / \mathrm{Al}_{2} \mathrm{O}_{3}$ and b $3 \% \mathrm{Ce}-10 \%$ $\mathrm{Co} / \mathrm{Al}_{2} \mathrm{O}_{3}$ after EGDR at stoichiometric feed ratio $\left(F_{\mathrm{CO}_{2}}=F_{\mathrm{C}_{2} \mathrm{H}_{6} \mathrm{O}_{2}}\right)$ and $T=998 \mathrm{~K}$

for spent $3 \% \mathrm{Ce}-10 \% \mathrm{Co} / \mathrm{Al}_{2} \mathrm{O}_{3}$ (see Fig. 8b) as it was most likely overlapped by the broad carbon peak.

Raman spectra of spent $10 \% \mathrm{Co} / \mathrm{Al}_{2} \mathrm{O}_{3}$ and $3 \% \mathrm{Ce}-10 \%$ $\mathrm{Co} / \mathrm{Al}_{2} \mathrm{O}_{3}$ in Fig. 9 show two distinctive peaks at around 1340.8 and $1580.1 \mathrm{~cm}^{-1}$. These peaks were attributed to D-band $\left(1340.8 \mathrm{~cm}^{-1}\right)$ representing the disordered structural form of amorphous or filamentous carbons, and $\mathrm{G}$ band $\left(1580.1 \mathrm{~cm}^{-1}\right)$ conforming to ordered graphite [28, 29]. The extent of carbon crystallinity can be justified using the relative integrated area of $\mathrm{D}-\mathrm{G}$ bands $\left(I_{\mathrm{D}} / I_{\mathrm{G}}\right)$. A small $I_{\mathrm{D}} / I_{\mathrm{G}}$ value demonstrates high crystallinity because of dominant amounts of graphitized carbon [30]. The $10 \% \mathrm{Co} / \mathrm{Al}_{2} \mathrm{O}_{3}$ showed a lower graphitization extent $\left(I_{\mathrm{D}} / I_{\mathrm{G}}=2.20\right)$ than $3 \% \mathrm{Ce}-10 \% \mathrm{Co} / \mathrm{Al}_{2} \mathrm{O}_{3}\left(I_{\mathrm{D}} / I_{\mathrm{G}}=1.63\right)$. However, as seen in Fig. 9, the peak intensity of unpromoted catalyst was superior to Ce-doped catalyst for both $\mathrm{D}-$ and $\mathrm{G}$ bands. The low Raman signal intensity for 3\% $\mathrm{Ce}-10 \% \mathrm{Co} / \mathrm{Al}_{2} \mathrm{O}_{3}$ proved the catalyst tolerance towards coking compared to $10 \% \mathrm{Co} / \mathrm{Al}_{2} \mathrm{O}_{3}$. This observation could be ascribed to the $\mathrm{CeO}_{2}$ redox properties resulting in simultaneous reduction of carbonaceous species from catalyst surface during EGDR [25].

Figure 10 displays the TPO profiles with respect to temperature for spent $10 \% \mathrm{Co} / \mathrm{Al}_{2} \mathrm{O}_{3}$ and $3 \% \mathrm{Ce}-10 \%$ $\mathrm{Co} / \mathrm{Al}_{2} \mathrm{O}_{3}$ after EGDR at stoichiometric feed ratio $\left(F_{\mathrm{CO}_{2}}=F_{\mathrm{C}_{2} \mathrm{H}_{6} \mathrm{O}_{2}}\right)$ and $T=998 \mathrm{~K}$. For both catalysts, the obvious weight drop was detected within the temperature range of $748-823 \mathrm{~K}$. The spent $10 \% \mathrm{Co} / \mathrm{Al}_{2} \mathrm{O}_{3}$ possessed a higher carbon content of $96.6 \%$ than that of $3 \% \mathrm{Ce}-10 \%$ $\mathrm{Co} / \mathrm{Al}_{2} \mathrm{O}_{3}(89.9 \%)$. The reduction in carbonaceous deposits was induced by the high basic property and great oxygen mobility of Ce promoter $[11,25]$. Siang et al. also proposed mechanistic steps [see Eqs. (15) and (16)] for the removal of carbonaceous deposits $\left(C_{x} H_{y}\right)$ from catalyst surface based on the redox cycling of $\mathrm{CeO}_{2}$ dopant [31]. The drop in carbon deposits on $3 \% \mathrm{Ce}-10 \% \mathrm{Co} / \mathrm{Al}_{2} \mathrm{O}_{3}$ could clarify its superior catalytic stability with time on stream in comparison with $10 \% \mathrm{Co} / \mathrm{Al}_{2} \mathrm{O}_{3}$ (see Fig. 7):

$2 x \mathrm{CeO}_{2}+\mathrm{C}_{x} \mathrm{H}_{y} \rightarrow x \mathrm{Ce}_{2} \mathrm{O}_{3}+x \mathrm{CO}+0.5 y \mathrm{H}_{2}$

$\mathrm{Ce}_{2} \mathrm{O}_{3}+\mathrm{CO}_{2} \rightarrow 2 \mathrm{CeO}_{2}+\mathrm{CO}$

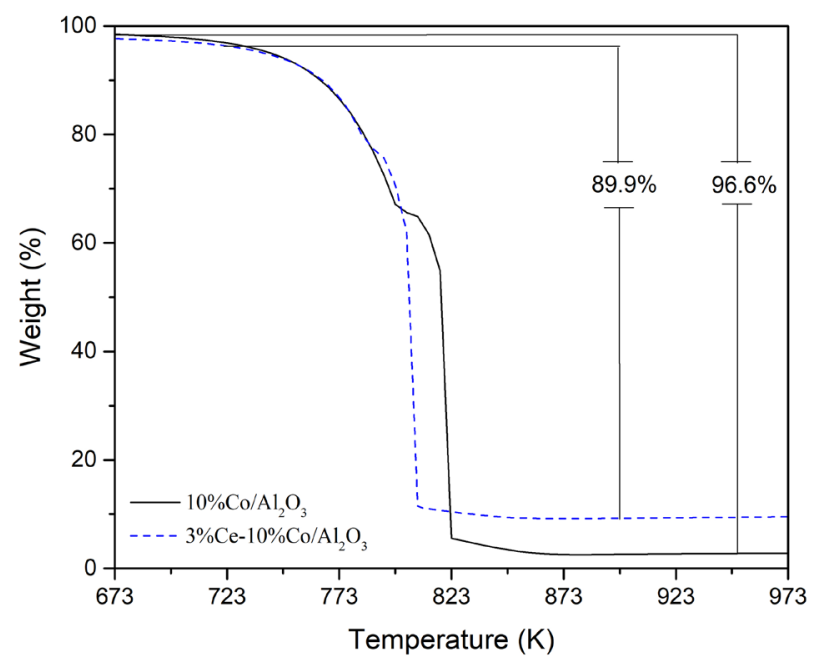

Fig. 10 Temperature-programmed oxidation profiles of used catalysts after EGDR at stoichiometric feed ratio $\left(F_{\mathrm{CO}_{2}}=F_{\mathrm{C}_{2} \mathrm{H}_{6} \mathrm{O}_{2}}\right)$ and $T=998 \mathrm{~K}$ 


\section{Conclusions}

It is the first time that EGDR reaction was successfully conducted to yield syngas using $10 \% \mathrm{Co} / \mathrm{Al}_{2} \mathrm{O}_{3}$ and $3 \% \mathrm{Ce}-10 \%$ $\mathrm{Co} / \mathrm{Al}_{2} \mathrm{O}_{3}$ catalysts. The addition of $\mathrm{Ce}$ promoter reduced the crystallite size of $\mathrm{Co}_{3} \mathrm{O}_{4}$, facilitated $\mathrm{Co}_{3} \mathrm{O}_{4}$ reduction in $\mathrm{H}_{2}$ and improved the catalytic performance of $10 \% \mathrm{Co} / \mathrm{Al}_{2} \mathrm{O}_{3}$. Increasing reaction temperature from 923 to $998 \mathrm{~K}$ enhanced catalytic activity and achieved the highest EG conversion of $71.7 \%$ and $\mathrm{H}_{2}$ yield of $69.3 \%$ at $998 \mathrm{~K}$ on $3 \% \mathrm{Ce}-10 \% \mathrm{Co} /$ $\mathrm{Al}_{2} \mathrm{O}_{3}$. The $\mathrm{H}_{2} / \mathrm{CO}$ ratio varied from 0.98 to 1.25 suitable for high-molecular weight hydrocarbon synthesis via FTS in downstream processes. The yield of $\mathrm{CH}_{4}$ intermediate product was trivial since it was subsequently converted into final $\mathrm{H}_{2}$ and $\mathrm{CO}$ gases by methane dry and steam reforming reactions.

Acknowledgements The research fund (UMP Research Grant Scheme, RDU170326) from Universiti Malaysia Pahang to carry out this work is thankfully acknowledged.

Open Access This article is distributed under the terms of the Creative Commons Attribution 4.0 International License (http://creativeco mmons.org/licenses/by/4.0/), which permits unrestricted use, distribution, and reproduction in any medium, provided you give appropriate credit to the original author(s) and the source, provide a link to the Creative Commons license, and indicate if changes were made.

\section{References}

1. Ni M, Leung DYC, Leung MKH (2007) A review on reforming bio-ethanol for hydrogen production. Int J Hydrog Energy 32:3238-3247

2. Li D, Li X, Gong J (2016) Catalytic reforming of oxygenates: state of the art and future prospects. Chem Rev 116:11529-11653

3. Chheda JN, Huber GW, Dumesic JA (2007) Liquid-phase catalytic processing of biomass-derived oxygenated hydrocarbons to fuels and chemicals. Angew Chem Int Ed 46:7164-7183

4. Abdullah B, Ghani NAA, Vo D-VN (2017) Recent advances in dry reforming of methane over Ni-based catalysts. J Clean Prod 162:170-185

5. Vo D-VN, Adesina AA (2011) Kinetics of the carbothermal synthesis of Mo carbide catalyst supported on various semiconductor oxides. Fuel Process Technol 92:1249-1260

6. Cabulong RB, Valdehuesa KNG, Ramos KRM, Nisola GM, Lee W-K, Lee CR, Chung W-J (2017) Enhanced yield of ethylene glycol production from D-xylose by pathway optimization in Escherichia coli. Enzyme Microb Technol 97:11-20

7. Pereira B, Zhang H, De Mey M, Lim CG, Li Z-J, Stephanopoulos G (2016) Engineering a novel biosynthetic pathway in Escherichia coli for production of renewable ethylene glycol. Biotechnol Bioeng 113:376-383

8. Wang S, Chen J, Chen L (2014) Selective conversion of cellulose into ethylene glycol over metal-organic framework-derived multifunctional catalysts. Catal Lett 144:1728-1734

9. Koichumanova K, Vikla AK, de Vlieger DJ, Seshan K, Mojet BL, Lefferts L (2013) Towards stable catalysts for aqueous phase conversion of ethylene glycol for renewable hydrogen. Chemsuschem 6:1717-1723

10. Sohn H, Ozkan US (2016) Cobalt-based catalysts for ethanol steam reforming: an overview. Energy Fuels 30:5309-5322

11. Fayaz F, Danh HT, Nguyen-Huy C, Vu KB, Abdullah B, Vo D-VN (2016) Promotional effect of Ce-dopant on $\mathrm{Al}_{2} \mathrm{O}_{3}$-supported $\mathrm{Co}$ catalysts for syngas production via $\mathrm{CO}_{2}$ reforming of ethanol. Procedia Eng 148:646-653

12. Ayodele BV, Khan MR, Cheng CK (2016) Catalytic performance of ceria-supported cobalt catalyst for CO-rich hydrogen production from dry reforming of methane. Int J Hydrog Energy 41:198-207

13. Budiman AW, Song S-H, Chang T-S, Shin C-H, Choi M-J (2012) Dry reforming of methane over cobalt catalysts: a literature review of catalyst development. Catal Surv Asia 16:183-197

14. Mei D, Lebarbier Dagle V, Xing R, Albrecht KO, Dagle RA (2016) Steam reforming of ethylene glycol over $\mathrm{MgAl}_{2} \mathrm{O}_{4}$ supported $\mathrm{Rh}, \mathrm{Ni}$, and Co catalysts. ACS Catal 6:315-325

15. Chu X, Liu J, Sun B, Dai R, Pei Y, Qiao M, Fan K (2011) Aqueous-phase reforming of ethylene glycol on $\mathrm{Co} / \mathrm{ZnO}$ catalysts prepared by the coprecipitation method. J Mol Catal A 335:129-135

16. Batista MS, Santos RKS, Assaf EM, Assaf JM, Ticianelli EA (2003) Characterization of the activity and stability of supported cobalt catalysts for the steam reforming of ethanol. J Power Sources 124:99-103

17. Yu S-W, Huang H-H, Tang C-W, Wang C-B (2014) The effect of accessible oxygen over $\mathrm{Co}_{3} \mathrm{O}_{4}-\mathrm{CeO}_{2}$ catalysts on the steam reforming of ethanol. Int J Hydrog Energy 39:20700-20711

18. Pardo-Tarifa F, Cabrera S, Sanchez-Dominguez M, Boutonnet $\mathrm{M}$ (2017) Ce-promoted $\mathrm{Co} / \mathrm{Al}_{2} \mathrm{O}_{3}$ catalysts for Fischer-Tropsch synthesis. Int J Hydrog Energy 42:9754-9765

19. Patterson AL (1939) The Scherrer formula for X-ray particle size determination. Phys Rev 56:978-982

20. Fischer N, van Steen E, Claeys M (2011) Preparation of supported nano-sized cobalt oxide and fcc cobalt crystallites. Catal Today 171:174-179

21. Liu Y, Jia L, Hou B, Sun D, Li D (2017) Cobalt aluminatemodified alumina as a carrier for cobalt in Fischer-Tropsch synthesis. Appl Catal A 530:30-36

22. Moodley DJ, Saib AM, van de Loosdrecht J, Welker-Nieuwoudt CA, Sigwebela BH, Niemantsverdriet JW (2011) The impact of cobalt aluminate formation on the deactivation of cobalt-based Fischer-Tropsch synthesis catalysts. Catal Today 171:192-200

23. (2000) JCPDS Powder Diffraction File. International Centre for Diffraction Data, Swarthmore

24. Braga TP, Essayem N, Valentini A (2017) Correlation between the basicity of $\mathrm{Cu}-\mathrm{M}_{\mathrm{x}} \mathrm{O}_{\mathrm{y}}-\mathrm{Al}_{2} \mathrm{O}_{3}(\mathrm{M}=\mathrm{Ba}, \mathrm{Mg}, \mathrm{K}$ or La) oxide and the catalytic performance in the glycerol conversion from adsorption microcalorimetry characterization. J Therm Anal Calorim 129:65-74

25. Amin R, Chang X, Liu B (2017) Synergistic effect of $\mathrm{CeO}_{2}$ in $\mathrm{CH}_{4} / \mathrm{CO}_{2}$ dry reforming reaction over stable $x \mathrm{CeO}_{2} y \mathrm{Ni} / \mathrm{MCM}-$ 22 catalysts. Ind Eng Chem Res 56:7445-7453

26. Kamonsuangkasem K, Therdthianwong S, Therdthianwong A, Thammajak N (2017) Remarkable activity and stability of $\mathrm{Ni}$ catalyst supported on $\mathrm{CeO}_{2}-\mathrm{Al}_{2} \mathrm{O}_{3}$ via $\mathrm{CeAlO}_{3}$ perovskite towards glycerol steam reforming for hydrogen production. Appl Catal B 218:650-663

27. Siang TJ, Pham TLM, Cuong NV, Phuong PTT, Phuc NHH, Truong QD, Vo D-VN (2018) Combined steam and $\mathrm{CO}_{2}$ reforming of methane for syngas production over carbon-resistant 
boron-promoted Ni/SBA-15 catalysts. Microporous Mesoporous Mater 262:122-132

28. Liu W-W, Chai S-P, Mohamed AR, Hashim U (2014) Synthesis and characterization of graphene and carbon nanotubes: a review on the past and recent developments. J Indus Eng Chem 20:1171-1185

29. Bahari MB, Phuc NHH, Alenazey F, Vu KB, Ainirazali N, Vo $\mathrm{D}-\mathrm{VN}$ (2017) Catalytic performance of $\mathrm{La}-\mathrm{Ni} / \mathrm{Al}_{2} \mathrm{O}_{3}$ catalyst for $\mathrm{CO}_{2}$ reforming of ethanol. Catal Today 291:67-75

30. Paksoy AI, Caglayan BS, Ozensoy E, Ökte AN, Aksoylu AE (2018) The effects of $\mathrm{Co} / \mathrm{Ce}$ loading ratio and reaction conditions on $\mathrm{CDRM}$ performance of $\mathrm{CoCe} / \mathrm{ZrO}_{2}$ catalysts. Int $\mathrm{J}$ Hydrog Energy 43:4321-4334
31. Siang TJ, Danh HT, Singh S, Truong QD, Setiabudi HD, Vo DVN (2017) Syngas production from combined steam and carbon dioxide reforming of methane over Ce-modified silica-supported nickel catalysts. Chem Eng Trans 56:1129-1134

Publisher's Note Springer Nature remains neutral with regard to jurisdictional claims in published maps and institutional affiliations. 